\title{
KONSELING KELOMPOK BERBASIS CLIENT CENTERED UNTUK MENURUNKAN KECEMASAN PADA LANSIA
}

\author{
Elsy Junilia ${ }^{1 *}$, Nurul Hidayah ${ }^{2}$ \\ 1,2Universitas Ahmad Dahlan Yogyakarta \\ Email: junilia.elsy@gmail.com
}

\begin{abstract}
ABSTRAK
Orang lanjut usia (lansia) memiliki kemungkinan lebih tinggi untuk mengalami gangguan kecemasan daripada depresi. Pengabdian kepada masyarakat ini bertujuan untuk menguji pengaruh konseling kelompok berbasis client-centered untuk menurunkan kecemasan pada lansia. Penelitian ini menggunakan pendekatan kuantitatif tipe eksperimen. Subjek penelitian ini berjumlah 6 wanita lansia dengan rentang usia 62-79 tahun di RW 03 wilayah kerja Puskesmas $X$. Hasil analisis data menggunakan SPSS menunjukkan koefisien $Z=-2,20$ dan $p$ $=0,116(\mathrm{p}<0,05)$ artinya ada penurunan kecemasan antara sebelum dan sesduah pemberian konseling kelompok berbasis Client-Centered (rerata skor pretes $=16$ dan rerata postes $=10$ ). Dapat disimpulkan bahwa konseling kelompok berbasis Client-Centered dapat menurunkan kecemasan pada lansia.
\end{abstract}

Kata kunci: lansia; cemas; Client Centered.

\begin{abstract}
The elderly has a high probability of anxiety disorder than despression. The type of this research was quantitative approach with quasi experiment. The subjects of this study were 6 elderly female in the age range of 62-79 years old who lived at RW 03 near the working area of Puskesmas X. The data analytic shows that the coefficient of $Z=-220$ and $p=0,116(p<0,05)$ mean there was a reducing of the anxiety between the beginning and after giving the counseling group with Client Centered method (the average of pretest score $=16$ and the average of posttest score $=10$ ). The conclusion of this research shows that counseling group with Client Centered method could reduce the anxiety disoder of the elderly.
\end{abstract}

Key words: elderly; anxiety; Client Centered

\section{PENDAHULUAN}

Lanjut usia (lansia) di Indonesia akhir-akhir ini semakin banyak mendapatkan perhatian karena fakta perubahan struktur demografi selama beberapa dekade terakhir dengan kecenderungan peningkatan penduduk berusia 60 tahun keatas yang cukup signifikan. Hal tersebut berdasarkan dari 217 juta jiwa penduduk Indonesia tercatat 17,3 juta atau hampir 8 persen diantaranya adalah penduduk yang berusia 60 tahun keatas yang telah mengalami kenaikan dua kali lipat dalam dua dekade menurut perkiraan Biro Pusat Statistik (BPS). Diperkirakan proyeksi peningkatan menjadi 25,5 juta pada tahun 2020 atau 
sebesar 11,37 persen dari jumlah penduduk yang artinya akan berada pada peringkat ke empat dunia di bawah Cina, India dan Amerika Serikat (SchoderButterfll, 2016). Kabid perlidungan dan Jaminan Sosial Dinas Sosial Kota Yogyakarta menyatakan bahwa saat ini jumlah lansia di Kota Yogyakarta mencapai 13 persen dari jumlah penduduk secara keseluruhan yaitu pada angka 45.000 lansia.

Tercatat pada Profil Kesehatan 2019 bahwa data tahun 2018 di Dinas Kesehatan Pemerintah Kota Yogyakarta jika secara keseluruhan pada kota Yogyakarta sebanyak 20.103 cakupan pelayanan kesehatan lanjut usia dari target yang ditentukan sebanyak 22.291 dengan reagen pemeriksaan gangguan mental emosional belum terpenuhi dengan alasan dibutuhkan waktu yang lama dan ketelitian serta menyangkut kurangnya jumlah psikolog. Kehilangan pekerjaan, kondisi ekonomi, peningkatan risiko terkena penyakit dan ketidakmampuan untuk berperan kembali dalam masyarakat yang sejalan dengan bertambahnya usia turut menjadi faktor predisposisi yang memudahkan lansia mengalami masalah mental (Singarimbun, 2012). Berdasarkan hasil wawancara dan observasi dengan pemegang program kesehatan lansia dan program jiwa, terdapat cukup banyak lansia mengalami gejala-gejala perubahan kondisi mental yang mengarah pada gangguan seperti cemas dan depresi.

Kecemasan sangat mengganggu homeostasis dan fungsi individu, karena itu perlu segera dihilangkan dengan berbagai macam cara penyesuaian (Maramis, 2013). Risiko ini akan semakin tinggi ketika terjadi pada lansia, apabila kecemasan ini tidak diatasi dengan baik, maka akan memberi dampak negatif. Berdasarkan permasalahan tersebut dan dalam upaya peningkatan derajat kesehatan masyaratkat utamanya lansia maka dianggap perlu dilaksanakan intervensi kelompok sebagai langkah preventif dalam menghadapi permasalahan lansia di wilayah kerja Puskesmas X di Kota Yogyakarta pada umumnya. Struat \& Sudden (2014) menyatakan bahwa faktor-faktor risiko tingkat kecemasan yaitu salah satunya jenis kelamin, stress sering dialami oleh wanita lebih tinggi dibandingkan laki-laki. Berdasarkan hal tersebut, peneliti tertarik untuk mengetahui tingkat kecemasan yang terjadi pada lansia terutama wanita di wilayah kerja Puskesmas $X$ di Kota Yogyakarta dengan melakukan intervensi model Client Centered.

Hal ini sesuai dengan penelitian yang dilakukan oleh Winoto (2016) pada tahun 2016 dengan judul “ Konseling Client Centered terhadap Pasien Psikosomatis" yang menyatakan bahwa model Client Centered yang diterapkan dalam konseling pada pasien psikosomatis menyebabkan para pasien menemukan kepercayaan diri untuk menyelesaikan permasalahannya dan juga kondisi fisik para pasien berangsur membaik bila dibandingkan dengan awal sebelum pelaksanaan konseling dengan model ini. Penelitian lain juga dilakukan oleh Utari (2019) dengan judul "Efektivitas Pendekatan Client Centered dengan Teknik Empathy dalam Layanan Konseling Kelompok terhadap Kecemasan Siswa Mengikuti Ujian Akhir Semester di Sekolah Menengah Atas PGRI Pekanbaru" yang menunjukkan bahwa kecemasan siswa sebelum diberikan layanan konseling kelompok dengan pendekatan Client Centered melalui teknik empathy berada dikategori sangat tinggi dengan rata-rata 88 dan persentase $97 \%$ dan setelah diberikan pendekatan Client Centered dengan teknik Empathy untuk mengatasi kecemasan siswa dalam mengikuti ujian akhir semester, mengalami perubahan menjadi kategori sangat rendah dengan rata-rata 32 dan persentase $28 \%$.

Penelitian ini bertujuan untuk menguji pengaruh konseling kelompok berbasis client-centered dalam menurunkan kecemasan pada lansia. 


\section{MASALAH}

Pengabdian masyarakat ini menggunakan pendekatan eksperimen dengan desain eksperimen semu (quasi experiment). Penelitian eksperimen merupakan metode penelitian yang digunakan untuk mencari pengaruh perlakuan tertentu terhadap yang lain dalam kondisi tertentu (Sugiyono, 2017).

Subjek pada pengabdian ini dipilih dengan menggunakan kriteria yang sudah dibuat oleh peneliti, yaitu merupakan anggota atau pengurus kader lansia, berjenis kelamin perempuan, berusia di rentang 60-80 tahun, dan berdomisili di wilayah kerja Puskesmas X. Pemilihan subjek dengan kriteria tersebut akhirnya diperoleh subjek berjumlah 6 orang yaitu RM (68), BP (77), BT(79), BH (72), BA (70), dan BR (62) yang merupakan warga lansia wanita di sekitar Puskesmas X. Penentuan subjek pengabdian dilakukan sejak 27 Januari 2020 melalui kader lansia.
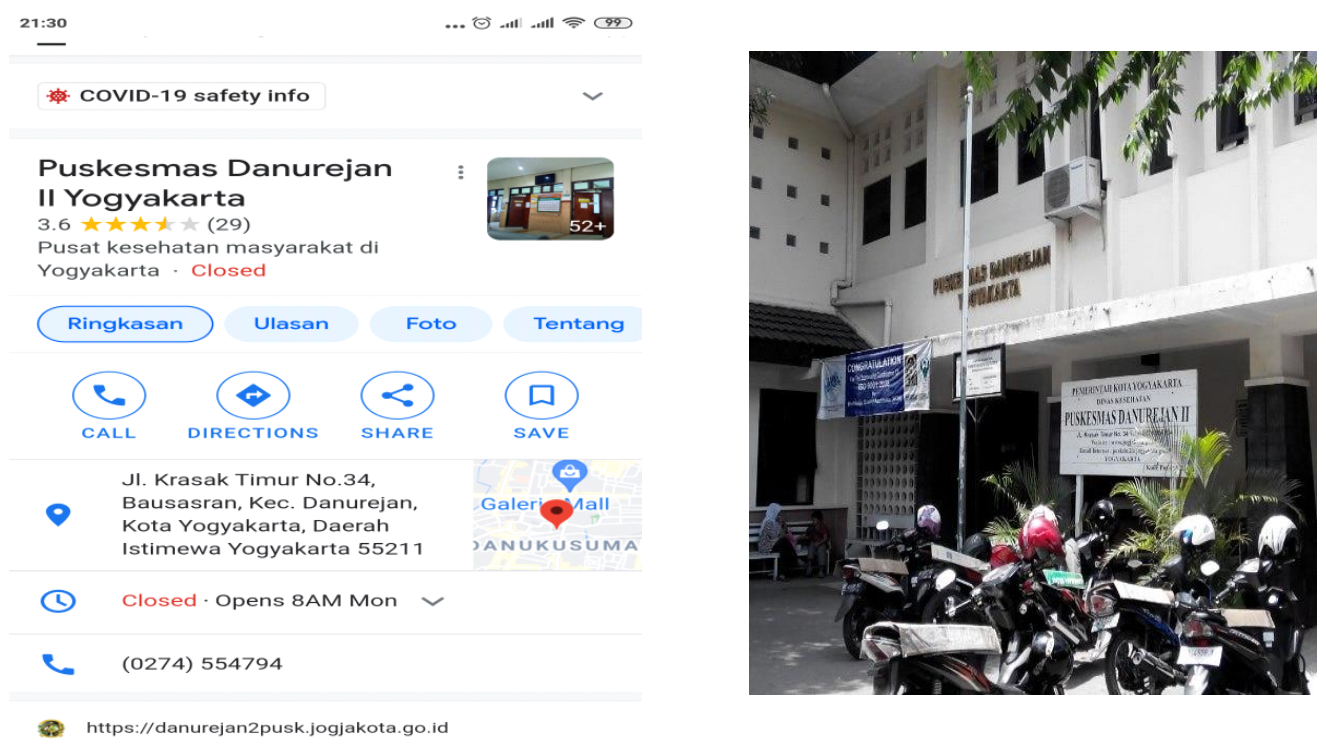

Gambar 2.1 Lokasi Pengabdian

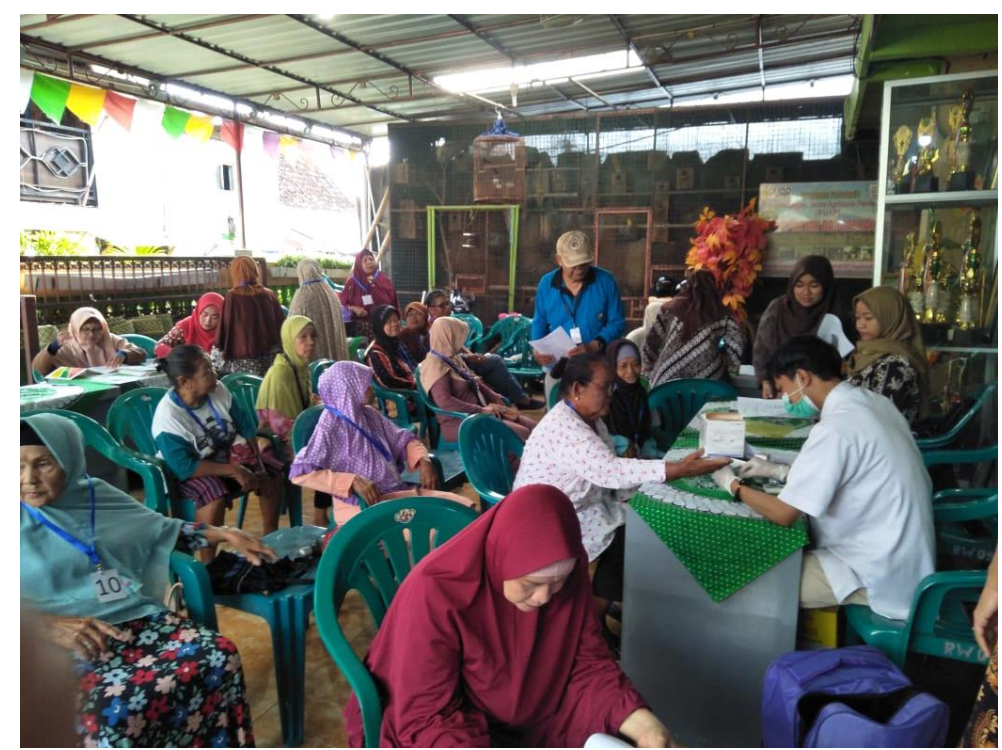

Gambar 2.2 Skrining Lansia dengan Kuesioner GAS 


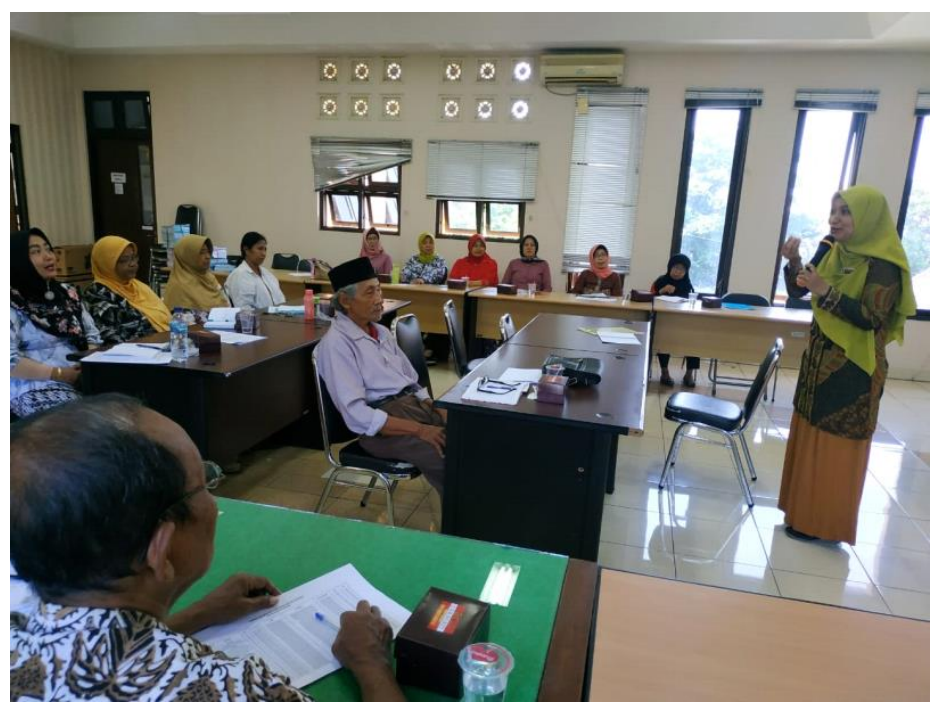

Gambar 2.3 Pelaksanaan FGD

Pada awalnya peneliti melakukan wawancara dan FGD dengan para koordinator kader lansia untuk merekomendasikan kader lansia yang sesuai dengan kegiatan intervensi kelompok. Berdasarkan hasil screening diperoleh 17 lansia yg memenuhi kriteria dan bersedia, namun hanya 6 subjek yg berhasil mengikuti jalannya pengabdian dari awal hingga akhir.

Pengumpulan data dilakukan dalam dua bentuk yaitu kuantitatif dan kualitatif. Pengumpulan data secara kuantitatif menggunakan skala yang digunakan sebagai alat pretest dan postest untuk menentukan tingkat kecemasan para peserta konseling kelompok adalah Geriatric Anxiety Scale (GAS). GAS terdiri dari 30 pertanyaan yang mengarah pada setiap gejala yang dialami selama dua minggu terakhir. Sistem menggunakan skala likert dimana masing-masing pertanyaan terdiri dari empat poin yaitu poin 0 tidak sama sekali, poin 1 kadangkadang, poin 2 sering, sampai dengan poin 3 yaitu sepanjang hari (Segal, 2013). GAS adalah salah satu alat ukur kecemasan yang dirancang dan digunakan khusus untuk lansia yang mencangkup aspek somatik, afektif dan kognitif yang dialami lansia dengan kecemasan (Yochim, dkk, 2010) dan instrumen ini akan digunakan sebagai alat ukur kecemasan di kelompok . Pengumpulan data dilakukan melalui Forum Group Discussioun (FGD), wawancara, dan observasi dengan sumber data utama adalah subjek penelitian.

\section{METODE}

Prosedur pelaksanaan eksperimen ini menggunakan beberapa tahapan dari Sukardi (2013). Pertama, peneliti melakukan pengkajian induktif berkaitan dengan gejala kecemasan pada lansia dan model Client Centered atau CCT. Proses kedua yang dilakukan peneliti yaitu melakukan identifikasi masalah dari gejala kecemasan yang dirasakan oleh para lansia.

Proses ketiga yaitu membuat rencana pengabdian, pada proses ini masih terdiri dari beberapa tahapan pula. Tahap pertama, peneliti melakukan identifikasi terhadap variabel luar yang mungkin tidak digunakan namun perlu dikontrol. Tahap kedua, peneliti menentukan cara agar dapat mengontrol mereka dengan memilih desain penelitian yang paling tepat. Tahap ketiga, peneliti menentukan 
berapa jumlah subjek yang akan digunakan dalam pengabdian dengan bantuan para koordinator kader lansia. Peneliti juga mempersiapkan instrumen dengan menggunakan GAS untuk mengetahui tingkat kecemasan para lansia serta membuat pedoman observasi dan FGD.

Proses keempat, peneliti melakukan eksperimennya melalui pengadaan pretest, posttest dan konseling CCT yang melibatkan 6 subjek dari wilayah kerja Puskesmas X. Proses konseling CCT ini berorientasi pada usaha subjek untuk melakukan self fullfillment (memenuhi kebutuhan kelompok untuk bisa beraktualisasi diri) yang menekankan pada konsep tentang diri dan menjadi diri atau perwujudan diri untuk mengatasi permasalahan, mencapai kebahagiaan atau menjadi individu yang berfungsi sepenuhnya. Komunikasi konseling kelompok menggunakan teknik terapeutik yang dibangun dan dapat menyediakan ruang yang aman bagi kelompok untuk menjelaskan perasaan, harapan dan kecemasan serta memberi ruang pada fasilitator untuk memberikan informasi dan emotional support ini dibagi menjadi dua tahap. Tahap pertama dari bulan Januari 2020 hingga awal Maret, konseling dilakukan secara tatap muka, sedangkan tahap evaluasi dilakukan melalui WhatsApp group.

Proses kelima, peneliti melakukan pengumpulan data ulang untuk dianalisis menjadi data yang terstruktur dan lebih bermakna. Terakhir, peneliti melakukan pembuatan laporan hasil pengabdian ini. Analisis data secara kuantitatif yang digunakan pada pengabdian ini analisis kuantitatif sederhana Analisis kuantitatif sederhana digunakan untuk mengetahui komparasi hasil pretest dan posttest dengan menggunakan perhitungan tes analitik deskriptif dari SPSS. Analisis secara kualitaif menggunakan triangulasi sumber berdasarkan hasil wawancara, FGD, dan observasi dengan subjek pengabdian maupun fasilitator.

\section{HASIL DAN PEMBAHASAN}

Pengabdian ini dilaksanakan sejak tanggal 27 Januari 2020 sampai 18 Maret 2020 di RW 03 wilayah kerja Puskesmas X dan dilakukan rutin setiap bulan pada tanggal 10 sebagai salah satu bentuk program kader lansia. Wabah pandemi COVID-19 menyebabkan FGD yang harusnya dilakukan secara tatap muka menjadi model daring melaui Grup WhatsApp. Pelaksanaan intervensi dilakukan setelah mendapatkan 6 kader lansia perempuan yang pasti mengikuti alur intervensi. Peneliti membagi kegiatan intervensi dalam 4 sesi pada setiap FGD. Sesi 1 berupa konseling kelompok (conducting, introduction, building rapport, informed concent, dan norma kelompok), sesi 2 berupa relaksasi, sesi 3 berupa sharing session, dan sesi 4 berupa evaluasi.

Hasil pengabdian ini menunjukkan adanya gejala kecemasan pada lansia yang berjenis kelamin perempuan dengan rentang usia antara 62-79 tahun. Dari 6 lansia, sebesar 83,3\% sebanyak 5 orang lansia mengalami gejala kecemasan ringan dan $16,7 \%$ sebanyak 1 orang mengalami gejala kecemasan sedang. Hasil pretest menunjukkan bahwa terdapat dua orang peserta yang memiliki skor intepretasi GAS dengan poin terendah yaitu 12 (subjek BT da BH) masuk dalam kategori kecemasan tingkat kecemasan ringan dan ada satu peserta yang memiliki skor intepretasi skala GAS tertinggi yaitu 23 (subjek BP) masuk dalam kategori Tingkat kecemasan sedang.

Pelaksanaan FGD dari sesi yang telah dilalui didapatkan hasil bahwa para responden lansia merasa cemas pada kejadian di masa yang akan datang sebesar $66,7 \%$ atau sebanyak 4 orang. Sebesar 33,3\% atau sebanyak 2 orang lansia merasa cemas karena masalah yang dihadapi pada saat yang bersamaan. Data tersebut dapat dilihat di Tabel 1. 
Tabel 1. Hasil FGD Assesmen Kecemasan Lansia

\begin{tabular}{|c|c|c|c|}
\hline No & Subjek & Usia & Hasil Assesmen \\
\hline 1 & RM & 68 & $\begin{array}{l}\text { Merasa cemas ketika memikirkan nasib dan masa } \\
\text { depan cucunya karena merasa ibunya tidak } \\
\text { menerapkan pola pengasuhan yang baik. }\end{array}$ \\
\hline 2 & $\mathrm{BP}$ & 77 & $\begin{array}{l}\text { Lansia yang tinggal sendiri dan melakukan } \\
\text { aktivitas secara mandiri dan sering merasakan } \\
\text { cemas ketika mengingat kematian. Beliau takut } \\
\text { jika tiba-tiba meninggal dalam keadaan } \\
\text { sendirian dan tidak ada yang menyadarinya. }\end{array}$ \\
\hline 3 & BT & 79 & $\begin{array}{l}\text { Merasa cemas karena telah terpilih menjadi } \\
\text { ketua perkumpulan lansia dengan masa tugas } \\
\text { dua tahun dan sedang terlibat konflik dengan } \\
\text { pengurus lainnya. }\end{array}$ \\
\hline 4 & $\mathrm{BH}$ & 72 & $\begin{array}{l}\text { Subjek selalu terbangun menjelang jam dua } \\
\text { malam dan sulit untuk kembali tidur. Subjek } \\
\text { takut jika hal ini terus berlanjut, maka subjek } \\
\text { akan mengalami penyakit atau akan } \\
\text { menimbulkan sakit di fisiknya saat ini. }\end{array}$ \\
\hline 5 & $\mathrm{BA}$ & 70 & $\begin{array}{l}\text { Merasa cemas jika sudah mengetahui hasil } \\
\text { periksa lab yang rutin di lakukan oleh pihak } \\
\text { puskesmas. }\end{array}$ \\
\hline 6 & BR & 62 & $\begin{array}{l}\text { Seorang ibu rumah tangga yang baru memasuki } \\
\text { usia lansia dan aktif berbisnis dengan membuka } \\
\text { bisnis catering pesanan dari rumah, subjek } \\
\text { merasa cemas jika suami pergi dan izin pergi } \\
\text { dinas ke luar kota. }\end{array}$ \\
\hline
\end{tabular}

Pada FGD sesi pertama anggota kelompok menyampaikan kecemasan yang dirasakan dalam konsep interpersonal yang berupa ketakutan akan penolakan interpersonal yang dihubungkan dengan trauma masa lalu yang berhubungan dengan kehilangan, perpisahan yang menyebabkan perasaan tidak berdayaan, perasaan cemas dominan bersumber pada self esteem yang rendah. Selain itu sebagian juga mengalami kecemasan karena hasil frustrasi (konsep perilaku) dari segala sesuatu yang mengganggu kemampuan mereka untuk mencapai tujuan yang diinginkannya dan muncullah kecemasan sebagai dorongan untuk menghilangkan rasa takut.

Di akhir sesi konseling setiap peserta menyampaikan support untuk anggota lainnya. Rangkaian proses konseling kelompok di sesi pertama ini secara umum berjalan dengan baik karena berhasil membuat kelompok saling menilai dengan positif dengan kondisi unconditional regard pada semua anggota kelompok. Adanya keselarasan dalam kelompok (congruen), mampu meliha permasalahan dengan sikap empatik dan melahirkan hubungan yang membawa akibat dan bersifat saling mendukung (supportive relationship). Hal tersebut tercapai karena anggota kelompok bersedia memberikan tanggapan, support dan kalimatkalimat yang bisa membuat peserta lansia lain mendapatkan insight dengan sendirinya.

Pada saat sesi kedua bagian relaksasi visual anggota kelompok lansia terlihat tenang ketika diinstruksikan untuk menumpahkan semua kekawatiran dan semua kecemasan pada selembar daun yang di peluk dan terlihat tersenyum ketika diminta untuk melepaskan semua kemarahan, kelelahan dan rasa kawatir mereka 
untuk hanyut bersama daun di tepi sungai. Diakui anggota kelompok merasa lega ketika mampu merelakan dan melepaskan semua bersama daun yang dihanyutkan di tepi sungai dan merasa lebih ringan.

Kegiatan sesi ketiga, subjek mengakui semenjak pertemuan pertama dan saling sharing, mereka mengalami banyak perubahan pada diri mereka terutama mulai mendeteksi respon fisik dan emosional lalu meredakannya dengan relaksasi nafas yang mereka lakukan secara mandiri. Sebagian dari peserta telah mampu menemukan pemaknaan yang berbeda terhadap masalah yang menimpa diri mereka dengan memakai sudut pandang yang lain seperti menyadari bahwa permasalahan yang mereka hadapi tidak seberat permasalahan yang terjadi pada yang lain dan memberikan insight bahwa ternyata semua orang mempunyai masalah dan bukan hanya dirinya saja, sehingga hadirnya kelompok membuat peserta tidak merasa sendiri.

Sesi keempat yaitu evaluasi dilakukan secara online dalam group konseling kelompok yang hanya berisikan anggota kelompok dan fasilitator, namun yang aktif hanya subjek BR yang sejak awal dipilih sebagai ketua kelompok dan karena anggota lainnya terkendala dalam penggunaan gadget. Di akhir sesi diskusi evaluasi terbatas, fasilitator meminta peserta lansia memberikan masukan pada proses konseling kelompok dan pada individu fasilitator dengan tujuan perbaikan dimasa yang akan datang dan boleh disampaikan secara langsung melalui tulisan atau melalui ketua kelompok yaitu subjek BR yang kemudian disampaikan ke fasilitator sebagai tugas ringan yang secara tidak langsung menjaga lansia anggota kelompok tetap saling terhubung ketika kelompok diharuskan menjaga jarak (physical distancing) dan hanya beraktivitas di rumah saja dalam kondisi pandemi COVID-19.

FGD yang dilakukan selama beberapa sesi telah menghasilkan penurunan tingkat kecemasan dari para lansia dengan prosentasi sebesar $100 \%$ lansia merasa di tingkat kecemasan paling ringan. Data tersebut dapat dilihat di Tabel 2.

Tabel 2. Hasil Evaluasi Tingkat Kecemasan Lansia Menggunakan Skala GAS

\begin{tabular}{|c|c|c|c|c|c|c|}
\hline $\begin{array}{l}\mathrm{N} \\
\mathrm{o} .\end{array}$ & Nama & $\begin{array}{c}\text { Skor } \\
\text { Pretest }\end{array}$ & Kategori & $\begin{array}{c}\text { Skor } \\
\text { postest }\end{array}$ & Katgeori & Selisih \\
\hline 1 & RM & 17 & $\begin{array}{c}\text { Tingkat } \\
\text { kecemasa } \\
\mathrm{n} \text { ringan }\end{array}$ & 10 & $\begin{array}{l}\text { Level } \\
\text { teringan } \\
\text { dari } \\
\text { kecemas } \\
\text { an }\end{array}$ & Turun 7 poin \\
\hline 2 & $\mathrm{BP}$ & 23 & $\begin{array}{c}\text { Tingkat } \\
\text { kecemasa } \\
\text { n sedang }\end{array}$ & 13 & $\begin{array}{l}\text { Level } \\
\text { teringan } \\
\text { dari } \\
\text { kecemas } \\
\text { an }\end{array}$ & Turun 10 poin \\
\hline 3 & BT & 12 & $\begin{array}{c}\text { Tingkat } \\
\text { kecemasa } \\
\mathrm{n} \text { ringan }\end{array}$ & 8 & $\begin{array}{l}\text { Level } \\
\text { teringan } \\
\text { dari } \\
\text { kecemas } \\
\text { an }\end{array}$ & Turun 4 poin \\
\hline 4 & $\mathrm{BH}$ & 12 & $\begin{array}{c}\text { Tingkat } \\
\text { kecemasa } \\
\mathrm{n} \text { ringan }\end{array}$ & 7 & $\begin{array}{l}\text { Level } \\
\text { teringan } \\
\text { dari }\end{array}$ & Turun 5 poin \\
\hline
\end{tabular}




\begin{tabular}{|c|c|c|c|c|c|}
\hline & & & & $\begin{array}{l}\text { kecemas } \\
\text { an }\end{array}$ & \\
\hline $5 \quad \mathrm{BA}$ & 14 & $\begin{array}{c}\text { Tingkat } \\
\text { kecemasa } \\
\mathrm{n} \text { ringan }\end{array}$ & 10 & $\begin{array}{l}\text { Level } \\
\text { teringan } \\
\text { dari } \\
\text { kecemas } \\
\text { an }\end{array}$ & Turun 4 poin \\
\hline $6 \quad B R$ & 18 & $\begin{array}{c}\text { Tingkat } \\
\text { kecemasa } \\
\mathrm{n} \text { ringan }\end{array}$ & 13 & & Turun 5 poin \\
\hline
\end{tabular}

Penurunan tingkat kecemasan lansia juga dapat dilihat dari hasil akumulasi baik pretest maupun posttest yang awalnya menunjukan angka 16 hingga akhirnya diperoleh angka 10 yang artinya terjadi penurunan tingkat kecemasan yang dialami oleh keenam peserta konseling kelompok.

Hasil konseling kelompok menunjukkan bahwa terdapat penurunan tingkat kecemasan kelompok dari semula pada angka mean 16,00 menjadi 10,00. Penurunan tingkat kecemasan termasuk signifikan $Z=-2,20(p=0,116, p \leq 0,05)$ yaitu pada angka 0,27 . Semua anggota konseling kelompok lansia mengalami penurunan skor pada post-test.

Proses intervensi yang dilakukan dengan pendekatan paradigma Humanistik melalui teknik Client Centre Therapy (CCT) menekankan pada unconditional positif regard diantara para peserta. Pada tahap persiapan, peneliti melakukan tes assesmen berupa wawancara dengan ketua kader lansia di RW 03 wilayah kerja Puskesmas X. CCT (Client-Centred Therapy) adalah salah satu bentuk intervensi humanistik yang dikembangkan oleh Carl Roger dimana fasilitator menyediakan kondisi atmosfir hangat dan bersifat suportif untuk meningkatkan konsep diri klien dan mendorong klien memperoleh pemahaman terhadap masalah yang sedang dihadapinya yang artinya CCT ini menekankan lebih pada refleksi diri client (Corey : 1986).

Beberapa gejala kecemasan yang dapat ditemukan pada lansia di RW 03 antara lain firasat buruk, susah untuk tidur, terbangun pada malam hari, sulit berkonsentrasi, merasa sedih, nyeri pada otot, rasa tertekan di dada, rasa tercekik, nafas pendek, serta ada rasa gelisah. Semua gejala tersebut adalah gejala yang banyak atau hampir semua dapat ditemui pada lansia dengan tingkat kecemasan sedang. Maka dampak dari gejala kecemasan tersebut akan dapat menimbulkan ketergantungan lansia terhadap aktivitas sehari-hari. Setengah dari anggota kelompok intervensi model CCT (subjek BT, subjek BR dan subjek BP) mengalami jantung berdegup kencang dan terkadang muncul keluhan nafas pendek. Berbagai penelitian sebenarnya menunjukkan bahwa di usia lansia jantung masih normal bekerja untuk mendistribusikan darah keseluruh tubuh. Kemampuan ini akan menjadi terbatas jika lansia merespon situasi yang menyebabkan cemas.

Secara teori, kecemasan akan membuat seseorang merasa yakin bahwa hal buruk akan terjadi, sehingga mengakibatkan rasa takut bahwa hal buruk tersebut merupakan hal yang nyata dan berujung pada penurunan aktivitas sehari-hari (APA: 2010). Hasil ini sesuai terhadap penelitian yang telah dilakukan sebelumnya oleh Hartanti tahun 2013 "Hubungan Tingkat Kecemasan Dengan Aktivitas Kehidupan Sehari-hari Pada Lansia di UPT Pelayanan Sosial Lanjut Usia Jember" dimana berdasarkan uji statistik menghasilkan nilai $p=0,004(p \leq 0,05)$. Hasil 
tersebut berarti bahwa, adanya hubungan yang bermakna antara tingkat kecemasan terhadap aktivitas kehidupan sehari-hari pada lansia.

Perbedaan pada pelaksanaan intervensi ini justru menimbulkan kemajuan dalam kelompok yang berjalan baik. Seperti subjek BP mengalami penurunan tingkat kecemasan paling tinggi yaitu sebanyak 10 poin hal ini diakui oleh subjek karena saat ini subjek merasa dirinya lebih memiliki alasan untuk semangat dengan memiliki teman kelompok yang saling men-support satu sama lain. Sementara itu subjek yang mengalami penurunan tingkat kecemasan yang paling rendah adalah subjek BT dan BA yaitu turun 4 poin tetap memiliki insight dan menyadari bahwa saling mendukung dalam kelompok mempengaruhi emosi dan bisa membuat berpikir lebih tenang dan lebih positif. Selain itu, subjek mampu berinteraksi dan memberikan support ke subjek lainnya setelah menyimak cerita mereka. Hal ini secara tidak langsung telah menciptakan dinamika kelompok yang baik sesuai tujuan kelompok sebelumnya karena seluruh peserta telah menjalani proses pemberdayaan kognitif.

Proses intervensi dengan model Client Centered ini telah membawa peserta juga menjadi saling belajar dari permasalahan peserta yang lain dan mulai belajar memahami orang lain, memperkuat empati dengan menyadari bahwa semua orang memiliki masalah dan memahaminya. Anggota kelompok juga secara tidak langsung membandingkan masalah yang dialaminya dengan anggota kelompok lainnya untuk kemudian dapat mengkoreksi dirinya sendiri tentang peniliannya terhadap dirinya sendiri dan reaksinya terhadap masalah yang dihadapinya, hal ini merupakan pencapian kelompok yaitu berkembang secara optimal sehingga mampu menjadi manusia yang berguna (Sukardi: 1984). Keterbatasan pada pengabdian ini yaitu sedikitnya subjek yang didapat karena pandemi COVID-19 yang kemudian juga menyebabkan komunikasi antara subjek dengan peneliti menjadi terbatas, dan desain pada penelitian ini bukan true experiment .

\section{KESIMPULAN DAN SARAN}

Berdasarkan hasil pengabdian dan pembahasan sebelumnya dapat disimpulkan bahwa proses saling bertukar pikiran dan berbagi cerita melalui intervensi kelompok dengan metode Client Centered sedikit banyak memengaruhi penurunan kecemasan para lansia ditunjukkan dengan hasil rerata pretest yang awalnya 16,00 turun dengan hasil rerata posttest menjadi 10,00. Berdasarkan hasil simpulan dari pengabdian ini, maka saran yang diperlukan yaitu pertama, bagi peneliti selanjutnya agar dilakukan penelitian berkaitan dengan metode Client Centered ini pada lansia laki-laki. Kedua, perlu adanya psikoedukasi kepada masyarakat melalui bantuan psikolog atau pihak yang berwenang terkait dukungan kelompok yang dapat mengurangi masalah psikologis individu. 


\section{DAFTAR PUSTAKA}

American Psychiatric Association. (2013). Diagnostic and Statistical Manual of Mental Disorder Edition (DSM-V). Washington : American Psychiatric Publishing.

American Psychological Association. (2010). Understanding Anxiety Disorders and Effective Treatment. Washington DC: American Psychiatric Publishing.

Hartanti, F.A. (2013). Hubungan Tingkat Kecemasan dengan Aktivitas Kehidupan Sehari-Hari pada Lansia Di Upt Pelayanan Sosial Lanjut Usia Jember. Skripsi, tidak diterbitkan. Fakultas Kedokteran Universitas Jember.

Heningsih. (2014). "Gambaran Tingkat Ansietas pada Lansia di Panti Wredha Dharma Bhakti Kasih Surakarta". Skripsi. Surakarta: Program Studi S-1 Keperawatan, Stikes Kusuma Husada Surakarta.

Maramis, F.W. (2005). Catatan Ilmu Kedokteran Jiwa. Surabaya : Airlangga.

Pramana, K. D., Okatiranti, \& Ningrum, T. P. (2016). Hubungan Tingkat Kecemasan Dengan Kejadian Hipertensi Di Panti Sosial Tresna Werdha Senjarawi Bandung. IV(2), 116-128.

Rogers, Carl. (1959). "A Theory Of Therapy, Personality And Interpersonal Relationships As Developed In The Client-Centered Framework". Vol. 3: Formulations of The Person and The Social Context. New York: McGraw Hill.

Schoder-Butterfill, E.M. (2016). Ageing in Indonesia: A Socio-demographic Approach.

Segal, R. (2013). Preventing Burnout: Signs, Symptoms, Causes, and Coping Strategies. Diunduh pada 14 Agustus 2020 dari http://www.helpguide.org/articles/stress/preventing-burnout.htm.

Singarimbun, M. (2012). Penduduk dan Perubahan. Yogyakarta. Pustaka Pelajar. Stuart \& Sundeen. (2014). Buku Saku Keperawatan Jiwa Edisi 3 alih bahasa Achir Yani. S. Jakarta: EGC.

Sugiyono. (2017). Metode Penelitian Kuantitatif, Kualitatif dan R\&D. Bandung: Alfabeta.

Sukardi. (2013). Metodologi Penelitian Pendidikan. Jakarta: Bumi Aksara.

Utari, S. (2019). Efektivitas Pendekatan Client Centered dengan Teknik Empathy dalam Layanan Konseling Kelompok terhadap Kecemasan Siswa Mengikuti Ujian Akhir Semester di Sekolah Menengah Atas PGRI Pekanbaru. Skripsi. UIN Suska Riau. Diakses pada 24 Agustus 2020 dari http://repository.uinsuska.ac.id/23024/1/UPLOAD\%20PUSTAKA\%20UNIV.pdf

Yochim, B.P., Mueller, A.E., Segal, D.L. (2013). Late Life Anxiety is Associated With Decreased Memory and Executive Functioning in Community Dwelling Older Adults. Journal of Anxiety Disorders.

Winoto, H.P. (2016) . Konseling Client Centered terhadap Pasien Psikosomatis. Jurnal Psikologi V (3). 154-155. Diakses pada 25 Agustus 2020 dari http://repository.iainpurwokerto.ac.id/343/1/Cover\%2CBabl\%2C\%20V\%2C \%20Daftar\%20Pustaka.pdf 